\title{
The Interaction of Rights of Relief and Unjustified Enrichment in Scots
}

\section{Law \\ Euan West*}

\section{A. Introduction}

Over the past four decades, the combined efforts of academics and the judiciary have served to transform the Scottish understanding of "unjustified enrichment", imposing structure on a legal area that was ill-defined and whose constituent causes of action were muddled and diffuse. ${ }^{1}$ In spite of this radical development, often dubbed the "enrichment revolution", ${ }^{2}$ debates persist as to the subject's scope and placement within the wider law of obligations. While there is broad consensus as to the internal organisation of the Scots law of unjustified enrichment, namely that it should be structured according to a modern civilian approach, ${ }^{3}$ uncertainties remain as to its boundaries, and the extent to which it overlaps with, even subsumes, other legal areas not hitherto associated with the reversal of enrichment. ${ }^{4}$ Notable among these taxonomical boundary disputes is the status of rights of relief, which allow one obligant to recover full or partial compensation from another obligant bound in the same obligation. ${ }^{5}$ In

\footnotetext{
* Lecturer in Law, University of Aberdeen. I am grateful to Robin Evans-Jones and Johann Dieckmann for their insightful comments on an earlier draft of this article.

${ }^{1}$ One of the main instigators of this development was Peter Birks in such articles as P B H Birks, "Six questions in search of a subject - unjust enrichment in a crisis of identity" [1985] JR 277. For an overview of his contribution and of the judicial and academic developments that followed, see H L MacQueen "Peter Birks and Scots enrichment law" in A Burrows and A F Rodger (eds), Mapping the Law: Essays in Memory of Peter Birks (2006) 401; M Hogg, "Unjustified enrichment in Scots law twenty years on: where now?" (2006) 14 RLR 1. On the judicial front, three cases were particularly significant: Morgan Guaranty Trust Company of New York $v$ Lothian Regional Council 1995 SC 151; Shilliday v Smith 1998 SC 725; Dollar Land (Cumbernauld) v CIN Properties 1998 SC (HL) 90. Subsequent academic writings have sought to systematise the law in the light of these decisions. See, e.g., N R Whitty, "Rationality, nationality and the taxonomy of unjustified enrichment" in D Johnston and R Zimmermann (eds), Unjustified Enrichment, Key Issues in Comparative Perspective (2002) 658; R Evans-Jones, Unjustified Enrichment, Vol 1, Enrichment by Deliberate Conferral: Condictio (2003); Hogg, Obligations (2nd edn, 2006); H L MacQueen, Law basics student study guides: unjustified enrichment, 3rd edn (2013); Evans-Jones, Unjustified Enrichment, Vol 2: Enrichment Acquired in Any Other Manner (2013); W M Gloag and R C Henderson, The Law of Scotland, 14th edn, by H L MacQueen et al (2017) ch 24. To this list of leading academic writings may be added Niall Whitty's forthcoming treatment of the Scots law of unjustified enrichment, which will form part of a reissue of the "Obligations" title of the Stair Memorial Encyclopaedia.

${ }^{2}$ Notably, in N R Whitty, "The Scottish enrichment revolution” (2001) 6 SLPQ 167.

${ }^{3}$ See Whitty, "Rationality" (n 1) and the other modern Scots law sources cited at n 1.

${ }^{4}$ Biffa Waste Services Ltd v Patersons of Greenoakhill Ltd [2015] CSOH 137, 2015 GWD 34-548 at para 29 per Lord Woolman.

${ }^{5}$ J Dalrymple, Viscount of Stair, The Institutions of the Law of Scotland 6th edn, D M Walker ed (1981) (based on the 2nd edn, 1693) I.8.2 and I.8.9 (hereinafter, "Stair, Inst"); G J Bell, Principles of the Law of Scotland, 4th edn (first published 1839, 2010) § 255; 10th edn, W Guthrie ed (1899) § 255 (unless specified otherwise, all subsequent references to Bell's Principles ("Bell, Prin") are to the fourth edition); J J Gow, The Mercantile and Industrial Law of Scotland (1964) 314-316; F Davidson et al (eds), Commercial Law in Scotland (5th edn, 2018) para 7.5.8.1.
} 
recent years, the Scottish judiciary has suggested that such rights exist to reverse, ${ }^{6}$ or prevent, ${ }^{7}$ unjustified enrichment: a view largely rejected by "enrichment" scholars, who insist that rights of relief and unjustified enrichment are distinct areas of law. ${ }^{8}$ While the debate features prominently in discussions of taxonomy and the structure of Scots private law, comparatively little has been said as regards its implications for litigants and practitioners, and the merits of framing a particular claim in terms of "relief" or "enrichment". The present article sets out to confront such issues by, inter alia, re-examining Reid v Lord Ruthven: a borderline case in which "enrichment" and "relief" seemed to vie for relevance. ${ }^{9}$ The aim is to clarify these legal areas' distinct, but often complementary, roles. Before comparing "relief" and "enrichment", however, it will be necessary to define each on its own terms.

\section{B. What Are Rights of Relief?}

\section{(1) Overview}

Rights of relief take a variety of forms of which the following is a simple example. Bob wishes to buy a car on credit. A finance company agrees to lend him the money on condition that his mother guarantees the monthly repayments of 100 as a secondary debtor known as a "cautioner". ${ }^{10}$ The upshot of this arrangement is that, if Bob defaults on his obligation to repay

\footnotetext{
${ }^{6}$ Moss v Penman 1993 SC 300 at 303; Christie's Executrix v Armstrong 1996 SC 295 at 297-298; Caledonia North Sea Ltd v London Bridge Engineering Ltd 2000 SLT 1123 at 1141; Joint Liquidators of Simclar (Ayrshire) Ltd v Simclar Group Ltd [2011] CSOH 54, 2011 SLT 1131 at paras 19, 20 and 34; Gillespie Investments $v$ Thomas Graham Gillespie [2011] CSOH 109, 2011 GWD 25-58 at para 20. Although the reasoning in the last decision was later rejected by the Inner House, there was no challenge to the Outer House's analysis of rights of relief as being rooted in unjustified enrichment: Gillespie Investments Ltd v Thomas Graham Gillespie [2012] CSIH 41, 2012 GWD 20-406.

${ }^{7}$ Villaswan $v$ Sheraton Caltrust (Blythswood) (in liquidation) 1999 SCLR 199 at 213; Gillespie Investments Ltd v John McLean Thomson Gillespie [2011] CSOH 108, 2011 GWD 25-557 at para 8.

${ }^{8}$ R Evans-Jones and P Hellwege, "Some observations on the taxonomy of unjustified enrichment in Scots law" (1998) 2 Edin LR 180 at 189; Whitty, "Rationality" (n 1) at 680; J A Dieckmann, "Province of subrogation determined: some corrections - a functional analysis of the guarantor's right to derivative recourse, comprising a critique of the restitutionary thesis" (2012) 20 Eur Rev Private L 989; idem, "Normative basis of subrogation and comparative law: select explanations in the common law, civil law and in mixed legal systems of the guarantor's right to derivative recourse" (2012) 27 Tul Eur \& Civ LF 49; Evans-Jones, Vol 2 (n 1) paras 2.47-2.48 and 2.64; Gloag and Henderson (n 1) para 3.15. In this regard, Scottish "enrichment" scholars are very much at odds with their English counterparts: A Burrows, The Law of Restitution, 3rd edn (2011) ch 17; G Virgo, The Principles of the Law of Restitution, 3rd edn (2015) 233-253. Cf C Mitchell, "Claims in unjustified enrichment to recover money paid pursuant to a common liability" (2001) 5 Edin LR 186, in which an attempt is made to rationalise, rather than to reject, the Scottish courts" "enrichment" analysis of rights of relief.

${ }^{9}$ (1918) 55 SLR 616.

${ }^{10}$ For details on the law of caution see, WM Gloag and JM Irvine, Law of Rights in Security, Heritable and Moveable Including Cautionary Obligations (W Green \& Sons 1897) chapters XIX-XXV; Gow (n 5) ch 5; W A Wilson, The Scottish law of debt, 2nd edn (1991) ch 10; A M Clark and S M Eden, "Cautionary Obligations and Representations as to Credit" in The Laws of Scotland: Stair Memorial Encyclopaedia vol 3 (1994); E A Marshall, Scots Mercantile Law, 3rd edn (1997) ch 8; S C Styles, "Rights in security" in A D M Forte (ed), Scots Commercial Law (Tottel Publishing 1997); S Eden and J T Pretorius, "Suretyship and cautionary obligations" in R Zimmermann, K Reid and D Visser (eds), Mixed Legal Systems in Comparative Perspective:
} 
the finance company 100 every month, his mother, in her capacity as cautioner, will be obliged to do so in his stead. ${ }^{11}$ However, if put to the trouble of paying 100 to the finance company, the mother will be entitled to reclaim that amount from her son via a right of total relief. ${ }^{12}$ Sometimes a cautioner's right of relief is merely partial. To alter the previous example, let it be supposed that both Bob's mother and father agree to stand cautioner for him. They become bound "jointly and severally" to the finance company, meaning that either one of them may be sued for the whole 100 should their son fail to pay. ${ }^{13}$ As before, the mother pays 100 to the finance company when Bob defaults, but, in this case, her right of total relief is of little use owing to her son's insolvency. Nevertheless, she enjoys a right of pro rata relief against her husband, entitling her to half of the amount paid to the finance company (50). ${ }^{14}$ A right of relief often consists, as in the previous examples, of a direct action against the party from whom relief is sought, but the pursuer might also desire an assignation of the creditor's rights. Thus, Bob's mother may, on paying the finance company 100, demand an assignation of the company's rights against her son. ${ }^{15}$ This can be useful in practice because, inter alia, it allows the cautioner to benefit from securities held by the creditor over the principal debtor's estate. ${ }^{16}$

Property and Obligations in Scotland and South Africa (2004) 335; Gloag and Henderson (n 1) ch 16; Davidson et al (eds) (n 5) ch 7; E West, "Cautionary Obligations" in The Laws of Scotland: Stair Memorial Encyclopaedia, Reissue (2019). For insight into the English law of suretyship, which has much in common with the Scots law of caution, see Rowlatt on Principal and Surety, 6th edn (2011).

${ }^{11}$ Morton's Trustees v Robertson's Judicial Factor (1892) $20 \mathrm{R} 72$ at 77; Scottish Metropolitan Property Plc v Christie 1987 SLT (Sh Ct) 18 at 22-23; E West, "Cautionary Obligations Reissue” (n 10) para 53.

$12 \mathrm{~J}$ Erskine, An Institute of the Law of Scotland, 1st edn (first published 1773, 2014) (hereinafter, "Erskine, Inst") III.3.65; Gloag and Irvine (n 10) 796-810; Smithy's Place Ltd v Blackadder and McMonagle 1991 SLT 790, 1991 SCLR 512; Caledonia North Sea Ltd v London Bridge Engineering Ltd 2000 SLT 1123 at 1141-1142 per Lord President Rodger.

${ }^{13}$ In such instances, the parties' liability is said to be in solidum rather than merely pro rata: Stair, Inst I.8.9, I.17.12 and I.17.20; Moss v Penman 1993 SC 300 at 303; Primary Healthcare Centres (Broadford) Ltd v Humphrey [2010] CSOH 129, 2010 GWD 35-730 at para 18. If cautioners become bound jointly and severally, this removes the "benefit of division", whereby each cautioner may be sued only for his pro rata share (albeit the size of the shares increases with the insolvency of the other cautioners): Bell, Prin $\S 267$. Similar, but not identical, rules apply outwith the context of caution: Coats v Union Bank of Scotland 1928 SC 711, revd 1929 SC (HL) 114; Scotts Atlantic Investments Ltd v Dryburgh [2014] CSOH 165, 2014 GWD 40-722; Gloag and Henderson (n 1) paras 3.14-3.19.

${ }^{14}$ Stair Inst I.8.9; A McDouall, Lord Bankton, An Institute of the Laws of Scotland in Civil Rights: With Observations upon the Agreement or Diversity between Them and the Laws of England (first published 17511753, 1993-1995) (hereinafter, Bankton, Inst) I.9.45 and I.23.42; Erskine Inst III.3.68; Gloag and Irvine (n 10) 810-826; Stirling v Forrester (1821) 3 Bligh 575 at 590; Buchanan v Main (1900) 3 F 215; Henderson v Skinner 1990 SLT (Sh Ct) 24; Caledonia North Sea Ltd v London Bridge Engineering Ltd 2000 SLT 1123 at 1141-1142. ${ }^{15}$ Erskine, Inst III.5.11; Ewart v Latta (1865) 3 M (HL) 36 at 40; Gloag and Irvine (n 10) 803-804. This right to an assignation is based on the beneficium cedendarum actionum of Roman law: Caledonia North Sea Ltd v London Bridge Engineering Ltd 2000 SLT 1123 at 1142-1144.

16 ibid. 
In more generalised terms, a right of relief is a claim by one obligant (D1) against another obligant (D2) in the same obligation, ${ }^{17}$ stemming from D1's fulfilment of the common obligation. ${ }^{18}$ While such rights have a strong association with the law of caution, their role extends to such analogous areas as co-principal liability, ${ }^{19}$ insurance ${ }^{20}$ and bills of exchange. ${ }^{21}$

\section{(2) Cause(s) of Action}

The law of obligations is concerned to explain what connects two parties, the pursuer and the defender, such as to vest a right in one and impose a correlative obligation on the other. In the case of rights of relief, the obligatory connection is sometimes contractual. If a prospective borrower persuades his friend to stand cautioner, it has often been said that there is a contract between the borrower and the cautioner akin to a mandate, and that any payments by the cautioner to the creditor can be treated as expenses flowing from that "mandate", hence recoverable from the borrower. ${ }^{22}$

The question remains: what is the basis of a cautioner's claim, if any, where he and the party from whom relief is sought have never met, still less entered into a contractual relationship? In such cases, a right of relief is said to spring from a certain conception of "equity"; ${ }^{23}$ one which receives a particularly lucid exposition in the writings of Lord Kames. ${ }^{24}$ In his view, rights of relief existed because a creditor with multiple debtors for the same debt should not be allowed arbitrarily to saddle one of those debtors with the whole burden thereof. ${ }^{25}$

\footnotetext{
${ }^{17}$ Here the phrase "same obligation" is used loosely. If two parties (D1 and D2) are liable jointly and severally to repay a debt of 100 , then it can be said that both are bound in a common obligation to pay 100. However, on a stricter definition of the word "obligation", there are actually two obligations here: that of D1 and that of D2. 18 "Relief" can also refer to a right to insist that a fellow obligant fulfil the common obligation: Doig v Lawrie (1903) 5 F 295. However, given that this form of relief has not been subjected to analysis in terms of unjustified enrichment, it is not discussed in this article.

${ }^{19}$ Muire v Chalmers (1682) Mor 14654; Stair I.8.9; Bankton Inst I.9.45; Erskine, Inst III.3.74; Moss v Penman 1993 SC 300; Primary Healthcare Centres (Broadford) Ltd v Humphrey [2010] CSOH 129, 2010 GWD 35-730 at paras 16-19.

${ }^{20}$ Caledonia North Sea Ltd v London Bridge Engineering Ltd 2000 SLT 1123, affd [2002] UKHL 4, 2002 SC (HL) 117; Sickness and Accident Assurance v General Accident Insurance Corporation (1892) 19 R 977.

${ }^{21}$ Bills of Exchange Act 1882 ss 55 and 57.

${ }^{22}$ Erskine Inst III.3.65; Bell, Prin, 4th edn and 10th edn, § 255; Baron D Hume, Lectures:1786-1822, vol II, G Campbell H Paton ed (1949) 214-215; Gloag and Irvine (n 10) 800-802; Smithy's Place Ltd v Blackadder and McMonagle 1991 SLT 790, 1991 SCLR 512.

${ }^{23}$ Murray v Creditors of Orchardtown (1722) Mor 14651 affd (1724) 1 Rob 465; Stirling v Forrester (1821) 3 Bligh 575 at 590; Thow's Trustees v Young 1910 SC 588 at 592; Union Bank v Taylor 1925 SC 835 at 841 ; W M Gloag, The Law of Contract: A Treatise on the Principles of Contract in the Law of Scotland, 2nd edn (1929) 206; Moss v Penman 1993 SC 300 at 303; Villaswan v Sheraton Caltrust (Blythswood) (in liquidation) 1999 SCLR 199 at 206 and 213.

${ }^{24}$ H Home, Lord Kames, "Beneficium cedendarum actionum" in idem, Essays upon Several Subjects in Law (1732) 19-60; idem, Principles of Equity, 3rd edn, M Lobban ed (first published 1778, 2014) 77-81. For a discussion of Kames' approach in a comparative context, see J A Dieckmann, "Normative basis" (n 8).

${ }^{25}$ Kames, Principles (n 24) 77-81.
} 
Where, for example, a creditor has two cautioners for a debt of 100, and one of those cautioners pays the full amount, the creditor is obliged to assign his rights to the paying cautioner so that the latter can recover pro rata relief from his co-cautioner (50). ${ }^{26}$ The result is a compromise between the creditor's convenience, allowing him to exact the whole debt from one source, and an ultimately equal distribution of liability between the cautioners. According to Kames, a creditor was obliged to assign the debt in such cases because it would have been arbitrary for him to refuse. ${ }^{27}$ Having received full payment, the creditor could in no way be prejudiced by an equitable redistribution of liability between the cautioners. Thus, somewhat counterintuitively, the connection grounding a right of relief is not so much between the debtors themselves as it is between the debtors and the creditor in the common obligation. ${ }^{28}$

Kames' non-contractual justification of relief is not without its complications. One might ask how a cautioner can obtain an assignation of the very rights that he purports to have discharged. To this apparent paradox, Roman law tendered the following solution: the cautioner, in paying the creditor, does not discharge the debt but rather "buys" the creditor's rights against the principal debtor and co-cautioners. ${ }^{29}$ On this view, long accepted in Scots law, ${ }^{30}$ there is no contradiction in the cautioner's founding his claim on payment of the creditor while also allowing him to demand an assignation. Though "tortured", ${ }^{31}$ the fiction is largely innocuous. Kames' non-contractual explanation for relief does not depend, for its normative potency, on the principal debtor's obligation having been discharged; relief is warranted so long as: (1) the cautioner paid the creditor in connection with the common obligation, thereby suffering loss; and (2) the creditor would not now be prejudiced by the cautioner's obtaining reimbursement from the other obligants.

The second conceptual difficulty is that a cautioner's non-contractual right of relief, despite being explained in terms of a right to an assignation from the creditor, does not necessarily take the form of an assignation in practice. As Kames himself noted, if the creditor

\footnotetext{
26 ibid.

27 ibid. See similarly, S Meier, "No Basis: A Comparative Overview" in A Burrows and A Rodger (eds), Mapping the Law: Essays in Memory of Peter Birks (2006) 343 at 360-361.

${ }^{28}$ A similar non-contractual explanation can be deployed for a cautioner's right of total relief against the principal debtor: Kames, Principles (n 24) 77-81; Erskine v Manderson (1780) Mor 1386; Sligo v Menzies (1840) 2 D 1478; Caledonia North Sea Ltd v London Bridge Engineering Ltd 2000 SLT 1123 at 1142-1144; Joint Liquidators of Simclar (Ayrshire) Ltd v Simclar Group Ltd [2011] CSOH 54, 2011 SLT 1131 at para 23. ${ }^{29}$ D.46.1.17; D 46.1.36; J A C Thomas, Textbook of Roman Law (1976) 337-338; S Meier, "Plurality of Parties" in N Jansen and R Zimmermann (eds), Commentaries on European Contract Laws (2018) 1557 at 1583.

${ }^{30}$ Bankton, Inst I.24.2; Kames, Principles (n 24) 77; Bell, Prin § 558; Caledonia North Sea Ltd v London Bridge Engineering Ltd 2000 SLT 1123 at 1143-1145.

${ }^{31}$ Caledonia North Sea Ltd v London Bridge Engineering Ltd 2000 SLT 1123 at 1143 per Lord President Rodger.
} 
refuses to grant an assignation, the law assumes that one has been granted because it ought to be granted. ${ }^{32}$ A formal assignation will be required in certain cases, most notably where the cautioner wishes to avail himself of the creditor's securities. ${ }^{33}$ However, even then, the assignation is simply the "machinery" with which the law sometimes gives effect to a right of relief, as against the principle to which that right is anchored $:{ }^{34}$ namely, the creditor's duty not to act arbitrarily to the paying cautioner's prejudice. ${ }^{35}$

So far, it should be clear that the term "right of relief" refers to at least two distinct causative events. Sometimes a right of relief arises from a contract, as is usually the case where a cautioner seeks reimbursement from his principal debtor. However, even in the absence of a contract between the pursuer and defender, a right of relief may arise on the basis of an equitable principle designed to prevent the creditor from acting arbitrarily. In either case, the pursuer's right can be justified on a basis entirely independent of unjustified enrichment: the focus of the next section. Indeed, rights of relief have traditionally been described in the language of "loss" rather than "enrichment". ${ }^{36}$ Having paid the creditor, the cautioner has "suffered loss", ${ }^{37}$ and his right of relief against the principal debtor or a co-cautioner allows him to demand compensation (either full or partial) for that loss. ${ }^{38}$ At any rate, there are certain rules relating to rights of relief for which unjustified enrichment cannot account, such as the creditor's duty to safeguard his real security rights prior to being paid. ${ }^{39}$ Thus, if there is a debt for which the creditor has both a cautioner and a real security over the principal debtor's estate, and the creditor relinquishes that security without the cautioner's consent, the creditor will lose his rights against the cautioner to the extent that the latter's right of relief has been prejudiced. ${ }^{40}$ It is by looking to Kames' non-contractual principle of relief, as opposed to unjustified enrichment, that one finds a satisfactory explanation for this rule. ${ }^{41}$ If a right of relief exists to

\footnotetext{
${ }^{32}$ Kames, Principles (n 24) 79. See also, Gloag and Irvine (n 10) at 814. This notion that a right of relief arises independently of an assignation is well-established in Scots law and continues to be affirmed: Stair, Inst I.8.9; Craigie v Graham (1710) Mor 14649; Bankton, Inst I.23.42; Erskine, Inst III.3.68 and III.3.74; Bell, Prin § 62 and 268; Henderson v Skinner 1990 SLT (Sh Ct) 24; Moss v Penman 1993 SC 300, 1994 SLT 19.

${ }^{33}$ Villaswan $v$ Sheraton Caltrust (Blythswood) (in liquidation) 1999 SCLR 199 at 210.

${ }^{34}$ Thow's Trustees $v$ Young 1910 SC 588 at 594 per the Lord Ordinary (Skerrington) and at 595 per Lord President Dunedin; Caledonia North Sea Ltd v London Bridge Engineering Ltd 2000 SLT 1123 at 1138 per Lord President Rodger; Joint Liquidators of Simclar (Ayrshire) Ltd v Simclar Group Ltd [2011] CSOH 54, 2011 SLT 1131 at para 18 per Lord Hodge.

${ }^{35}$ Kames, Principles (n 24) 77-81.

${ }^{36}$ Erskine Inst III.3.74; Trades House of Glasgow v Ferguson 1979 SLT 187 at 191-192 per Lord Justice-Clerk Wheatley; Ross, Harper \& Murphy v Banks 2000 SC 500 at para 14 per Lord Hamilton.

${ }^{37}$ Kames, Principles (n 24) 77.

38 ibid 77-81.

${ }^{39}$ Sligo v Menzies (1840) 2 D 1478; Marshall v Pennycook 1908 SC 276 at 282-286; Bank of Ireland v Morton 2003 SC 257 at para 14.

40 ibid.

${ }^{41}$ Kames, Principles (n 24) 78; Dieckmann, "Province" (n 8) at 1035-1036.
} 
prevent the creditor from acting arbitrarily, then, by the same token, the creditor should not be permitted arbitrarily to impair that right of relief by abandoning a security from which the cautioner later stands to benefit.

\section{What Is Unjustified Enrichment?}

(1) Overview

Unjustified enrichment consists of the defender, D, being enriched at the pursuer $(\mathrm{P})$ 's expense in circumstances requiring $\mathrm{D}$ to surrender that enrichment. ${ }^{42}$ Despite the antiquity of its constituent causes of action, which originate from Roman law, ${ }^{43}$ the notion that these form part of a body of law called "unjustified enrichment" is relatively modern. For Scots law, one of the key milestones in this development was the Inner House decision in Shilliday $v$ Smith:

[A] person may be said to be unjustly enriched at another's expense when he has obtained a benefit from another's actings or expenditure, without there being a legal ground which would justify him in retaining that benefit. ${ }^{44}$

Thanks to this principle, and an even wider formulation thereof advanced by Lord Hope ${ }^{45}$ it can now be said that all claims in unjustified enrichment involve the restoration of a benefit retained without a "legal ground". However, because claims in unjustified enrichment take a wide variety of forms, it is nigh impossible to provide this notion with a single concrete meaning. ${ }^{46}$ The solution, argue "enrichment" scholars, is to give the term "without legal ground" different meanings depending on the context in which it is used. Drawing on the experience of German law, ${ }^{47}$ these scholars contend that the Scots law of unjustified enrichment should be organised according to the way in which D's enrichment occurred, the key division being between: (1) an enrichment that $\mathrm{P}$ intentionally conferred on $\mathrm{D}$ for a particular purpose; and (2) an enrichment that D acquired from $\mathrm{P}$ in some "other" manner. ${ }^{48}$

\footnotetext{
42 Dollar Land (Cumbernauld) Ltd v CIN Properties Ltd 1998 SC (HL) 90 at 98-99. For details on this area of law, see the sources cited at $\mathrm{n} 1$.

${ }^{43}$ See generally, R Zimmermann, The Law of Obligations: Roman Foundations of the Civilian Tradition (first published 1990, 1996) ch 26.

441998 SC 725 at 727 per Lord President Rodger (emphasis added).

${ }^{45}$ Dollar Land (Cumbernauld) Ltd v CIN Properties Ltd 1998 SC (HL) 90 at 98-99.

${ }^{46}$ R Zimmermann and J du Plessis, "Basic features of the German law of unjustified enrichment" (1994) 2 RLR 14 at 24; G Dannemann, The German Law of Unjustified Enrichment and Restitution: A Comparative Introduction (2009) at 22-23.

${ }^{47}$ For details see, e.g., B Dickson, "The law of restitution in the Federal Republic of Germany: a comparison with English law" (1987) 36 ICLQ 751; Zimmermann and du Plessis (n 46); Dannemann, German Law (n 46); idem, "The future of German unjustified enrichment law" (2017) 25 RLR 44. For a criticism of the German approach, see N Jansen, "Farewell to unjustified enrichment?" (2016) 20 Edin LR 123.

48 The so-called "Wilburg/von Caemmerer" typology: see Dannemann, German Law (n 46) at 21-25 and the other sources cited at nn 46-47. With regard to Scots law's adoption of this framework see: Whitty,
} 
In spite of its generality, the requirement that an enrichment be "without legal ground" should be regarded only as a necessary, rather than a sufficient, element of a claim in unjustified enrichment. There may be other requirements, besides the absence of a legal ground, for an enrichment to be regarded as unjustified, and this will depend on the particular nature of the pursuer's "enrichment" claim. ${ }^{49}$ For instance, in Scots law the claim to recover an undue benefit (the condictio indebiti) requires not only that the defender's enrichment be "without legal ground" in the sense that the benefit was undue, but also proof that the pursuer conferred the benefit in the erroneous belief that it was due. ${ }^{50}$ Further, any enrichment claim may be defeated if it would not be "equitable" to compel redress. ${ }^{51}$

The significance of D's being enriched unjustifiably at P's expense is that D will be obliged to surrender his enrichment to $\mathrm{P} .{ }^{52}$ It is a distinguishing feature of such claims that $\mathrm{P}$ 's measure of recovery is limited to D's enrichment at his expense, even if that enrichment is lower than P's loss. ${ }^{53}$ Conversely, if D's enrichment exceeds P's loss, P's claim will usually, but not invariably, ${ }^{54}$ be capped at his loss. ${ }^{55}$

\section{(2) Particular Types of Unjustified Enrichment}

As indicated above, the statement that an enrichment lacks a "legal ground" assumes different meanings depending on the manner of the defender (D)'s enrichment at the pursuer (P)'s expense, the two main categories being: (1) an enrichment that was "deliberately conferred" by $\mathrm{P}$ on $\mathrm{D}$; and (2) an enrichment that $\mathrm{D}$ acquired in some other manner. ${ }^{56}$

\footnotetext{
"Rationality" (n 1) 693-694; Evans-Jones, Vol 1 (n 1); Hogg, "Twenty years on" (n 1) at 11-14; idem, Obligations (n 1) paras 4.40-4.79; MacQueen, Law Basics (n 1); Evans-Jones, Vol 2 (n 1); Gloag and Henderson (n 1) paras 24.08-24.20; MacQueen "The future of unjustified enrichment in Scotland" (2017) 25 RLR 14 at 22 24.

49 There is a neo-civilian controversy as to whether "without legal ground" should be used in a narrow sense (to refer, e.g., to the fact that the pursuer's purpose has failed) or in a broader sense (to refer to all elements of a successful claim in unjustified enrichment, including, but not limited to, a failure of purpose): $\mathrm{J}$ du Plessis, "Labels and meaning: unjust factors and failure of purpose as reasons for reversing enrichment by transfer" (2014) 18 Edin LR 416 at 431-432. In this article, "without legal ground" is used in the narrow sense. For further difficulties regarding the requirement that an enrichment be "without legal ground", see S Meier, "No Basis" (n 27); Hogg, "Twenty years on" (n 1) at 8-15.

${ }^{50}$ Morgan Guaranty Trust Company of New York v Lothian Regional Council 1995 SC 151.

${ }^{51}$ Dollar Land (Cumbernauld) Ltd v CIN Properties Ltd 1998 SC (HL) 90 at 98-99 per Lord Hope.

${ }^{52}$ For further details, see Shilliday v Smith 1998 SC 725 at 727-728 per Lord President Rodger.

${ }^{53}$ MacQueen, "Future" (n 48) at 21.

${ }^{54}$ Cf Secretary of State for Defence v Johnstone 1997 SLT (Sh Ct) 37.

${ }^{55}$ MacQueen, "Future" (n 48) at 21.

${ }^{56}$ Evans-Jones, Vol 1 (n 1); Hogg, Obligations (n 1) paras 4.45-4.46; MacQueen, Law Basics (n 1) 26; EvansJones Vol 2 (n 1); Gloag and Henderson (n 1) paras 24.08-24.15.
} 
If $\mathrm{P}$ enriched D intentionally, the latter's enrichment will lack a "legal ground" if the legally recognised purpose for which $\mathrm{P}$ bestowed it failed in some material way. ${ }^{57}$ The classic example is that of payment of money that is not due. If $\mathrm{P}$ pays 100 to $\mathrm{D}$ in the erroneous belief that he owes that amount to D, the latter's enrichment will lack a "legal ground" in the sense that P's purpose, namely to fulfil a debt, has failed. ${ }^{58}$ As a result, $\mathrm{P}$ will be able to recover the 100 from D under a claim known as the condictio indebiti. ${ }^{59}$ The converse also applies. If P's intention in paying 100 to $\mathrm{D}$ is to discharge a debt, and that debt exists, $\mathrm{P}$ 's purpose in enriching D succeeds, meaning that D now retains the money with a legal ground; or, in more compressed terms, the existence of a contract between $\mathrm{P}$ and D is D's legal ground for retaining the $100 .^{60}$ Besides the condictio indebiti, there exist a number of other condictio causes of action, most of which correspond, broadly, to the notion of a purpose failing. ${ }^{61}$ To cite another prominent example, if $\mathrm{P}$ gives $\mathrm{D}$ an engagement ring only to be rebuffed several weeks later, $\mathrm{P}$ may recover the ring on the ground that the purpose for which he conferred it (marriage) failed to materialise (condictio causa data causa non secuta). ${ }^{62}$ This notion of a purpose failing is a useful analytical starting point in modern unjustified enrichment cases. In considering whether a particular enrichment is "without legal ground", it is often worthwhile to ask for what purpose it was conferred (e.g. to discharge a debt) and whether that purpose failed (e.g. because the putative debt did not exist). From there, it becomes possible to identify which of the specific condictio claims, if any, might apply.

In the "other" group of cases, $\mathrm{P}$ does not intend to enrich D for a certain purpose; consequently, there is no question of P's purpose in enriching D having failed. In what sense, then, can D's enrichment be said to lack a "legal ground"? In these cases, an enrichment may

\footnotetext{
${ }^{57}$ This reflects a modern civilian interpretation of the "without legal ground" concept: Zimmermann, Obligations (n 43) 889; J du Plessis, "Towards a rational structure of liability for unjustified enrichment: thoughts from two mixed jurisdictions" (2005) 122 SALJ 142 at 173; idem, "Labels" (n 49) at 417 and 426-432. ${ }^{58}$ Evans-Jones, Vol 1 (n 1) para 3.01; du Plessis, "Labels" (n 49) at 417 and 428.

$59 \mathrm{ibid}$. The condictio indebiti is the claim to recover an undue benefit: Balfour $v$ Smith and Logan (1877) $4 \mathrm{R}$ 454; Morgan Guaranty Trust Company of New York v Lothian Regional Council 1995 SC 151; Alliance Trust Savings Ltd v Currie and others [2016] CSOH 154, 2017 SCLR 685.

${ }^{60}$ The latter meaning reflects an "objective" understanding of the term "without legal ground". In some scholars' eyes, the absence of a legal ground refers to the failure of the pursuer's legally recognised purpose ("subjective" approach); for others, the absence of a legal ground denotes the absence of a relationship of indebtedness between the pursuer and defender such as a contract, will or gift ("objective" approach): du Plessis, "Labels" (n 49) at 431-432. For the most part, this article favours the "subjective" approach. ${ }^{61}$ Evans-Jones, "Receptions of law, mixed legal systems and the myth of the genius of Scots private law" (1998) 114 LQR 228 at 233.

${ }^{62}$ The claim to recover a benefit given for a non-contractual future purpose that failed. Notable applications include: Shilliday v Smith 1998 SC 725; Satchwell v McIntosh 2006 SLT (Sh Ct) 117, 2006 GWD 27-599; Thomson v Mooney [2013] CSIH 115, 2014 Fam LR 15. Cf Courtney's Executors v Campbell [2016] CSOH 136, 2017 SCLR 387.
} 
lack a "legal ground" in three broad scenarios: ${ }^{63}$ (1) D "interfered" with P's property by selling it, consuming it or making it into a new thing, ${ }^{64}$ (2) P unwittingly "imposed" an enrichment on $\mathrm{D}$ (as where P constructs a house on D's land in the belief that the land belongs to him (P)); ${ }^{65}$ and (3) $\mathrm{P}$ voluntarily discharged D's legal obligation. ${ }^{66}$ Of all the forms of unjustified enrichment, the main one to interact with, and sometimes be conflated with, rights of relief is that relating to the voluntary fulfilment of another's obligation (3). That claim is now examined in detail.

\section{(3) Unjustified Enrichment via the Fulfilment of Another's Obligation}

"Enrichment" scholars tend to agree that, if $\mathrm{P}$ voluntarily pays D's debt, ${ }^{67} \mathrm{P}$ has a potential claim against $\mathrm{D}$ in unjustified enrichment, ${ }^{68}$ although the word "voluntarily" has a very precise meaning in this context. ${ }^{69}$ Provided that P's payment successfully discharges D's debt, ${ }^{70}$ the latter will be obliged to recompense $\mathrm{P}$ for his enrichment, which consists of the saving acquired from no longer having to fulfil his debt. ${ }^{71}$ However, the circumstances in which $\mathrm{P}$ would contemplate raising such an "enrichment"-based claim tend to be fairly specialised; ${ }^{72}$ something which becomes clear if one considers the various reasons for which one might pay another's debt. The main possibilities are as follows:

(1) The payment of the debt was a gift to the debtor;

\footnotetext{
${ }^{63}$ Evans-Jones, Vol 2 (n 1); MacQueen, "Future" (n 48) 22; Dannemann, "Future" (n 47) 44-45. In some academic treatments of the Scots law of unjustified enrichment, the fulfilment of another's obligation is treated as a sub-category of "imposition": Gloag and Henderson (n 1) paras 24.18-24.19.

${ }^{64}$ Oliver and Boyd v Marr Typefounding Co Ltd (1901) 9 SLT 170; HarperCollins Publishing Ltd v Young [2007] CSOH 65.

${ }^{65}$ Beattie v Lord Napier (1831) 9 S 639; Barbour v Halliday (1840) 2 D 1279.

${ }^{66}$ Reid v Lord Ruthven (1918) 55 SLR 616.

${ }^{67}$ Limitations of space preclude consideration of the performance of another's obligation ad factum praestandum and the additional complexities created by such cases. See, e.g., Transco Plc v Glasgow City Council 2005 SLT 958.

${ }^{68}$ See, e.g., Evans-Jones, Vol 2 (n 1) ch 6.

${ }^{69}$ The payment is voluntary in the specific sense that the payer is not legally bound to pay and does not consider himself to be legally bound. At the same time, "voluntary" does not necessarily mean "as a gift to the debtor". As will become clear in due course, one might voluntarily pay another's debt, fully in the knowledge that one could never have been compelled to pay it, but still expect to be reimbursed by the debtor. Conversely, a payment made by a cautioner or co-obligant who has not been sued (as in Moss v Penman 1993 SC 300) is not voluntary because it is still made for the purpose of discharging a legal obligation. Note also, that where someone pays in the erroneous belief that he was bound to pay, that payment is not voluntary for the purposes of this article because it was paid with the intention of discharging a legal obligation. Nevertheless, the payer may be able to reclaim the money from the creditor under the condictio indebiti. For further details, see text to nn 131-137 below.

${ }^{70}$ Bell, Prin $§ 557 ;$ Reid v Lord Ruthven (1918) 55 SLR 616.

${ }^{71}$ Gloag and Henderson (n 1) para 24.18.

${ }^{72}$ See similarly the position in German law, wherein the claim of a voluntary payer of another's debt against the debtor is very rarely addressed in terms of unjustified enrichment: Dannemann, "Future" (n 47) at 45-46 and 51.
} 
(2) The payment was made in accordance with a contract between the payer and the debtor;

(3) The payment was made for the debtor's benefit but without his permission and in the hope of reimbursement from the debtor;

(4) The payment falls outwith the above categories.

Scenario 1 is straightforward. Where, say, a mother pays off her son's overdraft, it is likely that she has no intention of reclaiming the money from him. Often, however, the payment of another's debt will be made in the expectation of reimbursement, and if the payer acted on the debtor's express instructions, he may enjoy a right of recovery under a contract of agency or mandate (scenario 2) ${ }^{73}$ It has even been suggested that, in the absence of an actual contract between the payer and the debtor, the payment of another's debt may trigger a relationship of "ad hoc agency" between them, ${ }^{74}$ but this analysis has been criticised as artificial and unnecessary: artificial because a contract of agency has traditionally depended on the existence of an agreement between agent and principal; unnecessary because, even if the payer acts without the debtor's authorisation or approval, he may still be able to reclaim the money on a non-contractual basis. ${ }^{75}$ One such is negotiorum gestio: a legal relationship arising not from agreement but from the benevolent management of another's affairs without the latter's knowledge or permission (scenario 3). ${ }^{76}$ Payment of another's debt is but one of the multifarious scenarios to which the doctrine applies. ${ }^{77}$ Suppose that Joyce incurs a parking fine, but, owing to illness or absence from the country, her friend Rachael pays it on her behalf. Provided that Rachael satisfies the requirements for a claim in negotiorum gestio, for instance the need for Joyce to have been absent, lacking in capacity or unaware of Rachael's

\footnotetext{
${ }^{73}$ Bell, Prin $§$ 226; Reid v Lord Ruthven (1918) 55 SLR 616 at 618. See also, Ligertwood v Brown (1872) $10 \mathrm{M}$ 832 in which P discharged D's obligation of aliment by caring for D's child: D was obliged to reimburse P for this under an implied contract.

${ }^{74}$ Whitbread Group Plc v Goldapple Ltd (No 2) 2005 SLT 281.

${ }^{75}$ See generally, L J Macgregor and N R Whitty, "Payment of another's debt, unjustified enrichment and ad hoc agency" (2011) 15 Edin LR 57, but especially at 74-86; Evans-Jones, Vol 2 (n 1) ch 6.

${ }^{76}$ Bankton, Inst I.9.24; Erskine, Inst III.3.52; Bell, Prin $§ 540$. For an overview of this area of law see N R Whitty, "Negotiorum gestio", in The Laws of Scotland: Stair Memorial Encyclopaedia vol 15 (1996) paras 87143.

${ }^{77}$ Graham's Exrs v Fletcher's Exrs (1870) 9 M 298 at 302 per Lord Ardmillan; Reid v Lord Ruthven (1918) 55 SLR 616 at 618; Whitty, "Negotiorum gestio" (n 76) para 97.
} 
intervention, ${ }^{78}$ she will, in principle, be entitled to "repayment of all necessary outlays" associated with her management of Joyce's affairs. ${ }^{79}$ Given that the payment of another's debt is likely to correspond to one of the three categories mentioned so far (scenarios 1-3), the cases to which scenario 4 caters will be fairly unusual. They tend to involve circumstances superficially similar to, but falling short of, negotiorum gestio (scenario 3), ${ }^{80}$ as where $\mathrm{P}$ acts when $\mathrm{D}$ is neither absent nor incapable of managing his affairs, ${ }^{81}$ or where P's intervention is for purely self-interested reasons. ${ }^{82}$ Perhaps $\mathrm{P}$ is the assignee of D's life assurance policy, for which $\mathrm{D}$ is liable to pay the premiums, yet, $\mathrm{D}$ having defaulted, $\mathrm{P}$ decides to pay the premiums in his stead. In these circumstances, P cannot be said to have acted as D's agent or even as his negotiorum gestor; he simply wished to prevent the policy from lapsing. Even so, because D's liability to the assurance company has been discharged, $\mathrm{P}$ is entitled to reclaim his payments from $\mathrm{D}$ as an unjustified enrichment at his (P's) expense. ${ }^{83}$

As with many other causes of action in the law of unjustified enrichment, the history of the "fulfilment of another's obligation" claim is complex. ${ }^{84}$ In seeking to understand it for the purposes of modern law, an appropriate starting point is the early twentieth century case of Reid v Lord Ruthven. ${ }^{85}$ The Lord Ordinary's decision therein, which was upheld by the Inner House, serves as a leading Scottish authority on unjustified enrichment via the voluntary payment of another's debt: ${ }^{86}$

What clothes [the voluntary payer of a third party's debt] with [his right to repayment by the debtor] is not an assignation but the fact that payment has been made, with no

\footnotetext{
${ }^{78}$ The other main requirements are that Rachael acted without Joyce's authorisation but for Joyce's benefit, and that the administration was at least initially useful to Joyce: Whitty, "Negotiorum gestio" (n 76) para 95; Gloag and Henderson (n 1) para 24.24.

${ }^{79}$ Kolbin \& Sons $v$ Kinnear \& Co 1930 SC 724 at 752 per Lord Ormidale.

${ }^{80}$ Evans-Jones, Vol 2 (n 1) paras 1.18, 1.21-1.22 and 1.26.

${ }^{81}$ Gilbert v Hannah 1924 SLT (Sh Ct) 86, (1924) 40 Sh Ct Rep 262.

82 If P's intervention is only partly self-interested, a relationship of negotiorum gestio may still exist: Kolbin \& Sons v Kinnear \& Co 1930 SC 724, affd 1931 SC (HL) 128.

${ }^{83}$ This example is based on such cases as Wylie's Executrix v M'Jannet (1901) 4 F 195 and Morgan v Morgan's Judicial Factor 1922 SLT 247.

${ }^{84}$ For a detailed treatment, see Evans-Jones, $\operatorname{Vol} 2$ (n 1) ch 1.

85 (1918) 55 SLR 616. Other cases relating to this form of unjustified enrichment include: Tod v Dunlop (1838) 1 D 231; Anderson v Blair (1841) 3 D 968; Brown v Meek's Trustees (1896) 4 SLT 46; Wylie's Executrix v M'Jannet (1901) 4 F 195; Duncan v Motherwell Bridge and Engineering Co Ltd 1952 SC 131; Morgan v Morgan's Judicial Factor 1922 SLT 247.

${ }^{86}$ H L MacQueen, "Payment of another's debt" in D Johnston and R Zimmermann (eds), Unjustified Enrichment: Key Issues in Comparative Perspective (2002) 458 at 470; Evans-Jones, Vol 2 (n 1) paras 6.526.54. However, some sources place more emphasis on the role of negotiorum gestio in Reid v Lord Ruthven: Discussion Paper on Recovery of Benefits Conferred Under Error of Law (Scot Law Com DP No 95, 1993) vol 2, para 2.159; Macgregor and Whitty (n 75) at 64.
} 
intention of donating, on behalf of a third party. The legal basis of his claim is the right to be repaid what he has disbursed for another. ${ }^{87}$

While, at first blush, this statement does not seem to relate to unjustified enrichment, it is couched in language intimately connected with that area of law. The Lord Ordinary was invoking what was then known as the principle of "recompense", a precursor of the modern law of unjustified enrichment whereby one who had "gained by the lawful act of another, done without any intention of donation" became obliged to the impoverished party "to the extent of the gain". ${ }^{88}$ This language is now largely ${ }^{89}$ outdated: in modern law, the term "recompense" is understood simply to be one of several responses with which to reverse unjustified enrichment, as against a principle or set of causes of action, ${ }^{90}$ with the result that many causes of action, hitherto grouped under the heading "recompense", have had to be rebranded as forms of "unjustified enrichment". ${ }^{91}$ One of the great achievements of "enrichment" scholars has been to reinterpret cases steeped in the outdated language of "recompense", 92 or which were otherwise opaque as to the cause of action, ${ }^{93}$ in terms of particular species of unjustified enrichment. Thus, although the claim relating to the voluntary payment of another's debt was initially couched in terms of "recompense", it is now recognised as a cause of action in unjustified enrichment. ${ }^{94}$

${ }^{87}$ (1918) 55 SLR 616 at 618 per Lord Anderson (emphasis added).

${ }^{88}$ Bell, Prin $\$ 538$ (emphasis added). This concept was refined in such cases as Edinburgh \& District Tramways Co Ltd v Courtenay 1909 SC 99 at 105-107 per Lord President Dunedin. For other references to "recompense" specifically to describe a claim associated with the fulfilment of another's obligation, see, e.g., Duncan $v$ Motherwell Bridge and Engineering Co Ltd 1952 SC 131; Morgan v Morgan's Judicial Factor 1922 SLT 247; Varney (Scotland) Ltd v Lanark Town Council 1974 SC 245.

${ }^{89}$ Of course, it is not completely outdated. The notion of D receiving a gain at P's expense is central to the modern law of unjustified enrichment: Dollar Land (Cumbernauld) Ltd v CIN Properties Ltd 1998 SC (HL) 90 at 98-99.

${ }^{90}$ Shilliday v Smith 1998 SC 725 at 728; P Hellwege, "Rationalising the Scottish law of unjustified enrichment" (2000) 11 Stellenbosch Law Review 50 at 60. This development has not prevented some judges from continuing to describe "recompense" as if it still referred to a distinctive cause of action: see, e.g., Transco Plc v Glasgow City Council 2005 SLT 958. However, this analysis is viewed as something of an aberration in modern law: N R Whitty, "Transco plc v Glasgow City Council: developing enrichment law after Shilliday" (2006) 10 Edin LR 113 at $115-116$.

${ }^{91}$ Evans-Jones, Vol 2 (n 1) paras 1.50-1.52.

92 E.g. Reid v Lord Ruthven (1918) 55 SLR 616; Duncan v Motherwell Bridge and Engineering Co Ltd 1952 SC 131.

${ }^{93}$ See, e.g., Tod v Dunlop (1838) 1 D 231, where the existence of a claim arising from the voluntary performance of another's debt was recognised but not explained.

${ }_{94}$ Macallans Ltd $v$ W Burrell Homes Ltd (No 2) 2017 SLT (Sh Ct) 1 at 3. This modern understanding of the "payment of another's debt" claim has been greatly influenced by the Rückgriffskondiktion of German law: Ernst von Caemmerer, "Bereicherung und Unerlaubte Handlung" in Festschrift für Ernst Rabel, Vol 1 (1954) 333 as cited in Zimmermann and du Plessis (n 46) at 25. For further information on the nature of this claim, see generally MacQueen, "Payment of another's debt" (n 86); Macgregor and Whitty (n 75); Evans-Jones, Vol 2 (n 1) ch 6. 


\section{Re-examining a Borderline Case: Reid v Lord Ruthven ${ }^{95}$}

Having defined rights of relief and unjustified enrichment, this article now sets out to elucidate how those areas interact via a re-examination of Reid v Lord Ruthven. As already mentioned, the case enjoys an important status in the Scots law of unjustified enrichment, and, while no attempt is made to gainsay that status here, it is suggested that the case may have other, hitherto untapped, insights to offer. The reasons for focusing on Reid are threefold. Firstly, it is not simply a case concerning unjustified enrichment: it is a leading case on a certain form of unjustified enrichment via the voluntary discharge of another's debt. ${ }^{96}$ Secondly, and in spite of the latter point, Reid is also highly relevant to rights of relief. Factually, it seems to sit on the borderline between "relief" and "enrichment", and, while the Outer House ultimately favoured an analysis based on "enrichment", it is submitted that the same result might more credibly have been reached via a non-contractual right of relief. The third reason for examining this case is that, hitherto, it has not been subjected to a "relief" analysis such as is attempted below. It is hoped that by reappraising the decision in this way, fresh light will be shed on the interface between rights of relief and unjustified enrichment.

\section{The Decision in Reid v Lord Ruthven}

In the simplest cases, rights of relief involve three parties, typically consisting of a cautioner, principal debtor and creditor. Reid $v$ Lord Ruthven was notable for involving two cautionary relationships:

\section{Relationship 1:}

Lord Ruthven (D) had borrowed money from the Bank of Scotland. Kirk (C1) was Ruthven's cautioner in respect of that indebtedness, guaranteeing that Ruthven would pay his debts to the bank. ${ }^{97}$

Relationship 2:

\footnotetext{
${ }^{95}$ Reid v Lord Ruthven (1918) 55 SLR 616.

${ }^{96}$ MacQueen, "Payment of another's debt” (n 86) at 470; Evans-Jones, Vol 2 (n 1) para 6.52-6.54.

${ }^{97}$ Reid v Lord Ruthven (1918) 55 SLR 616 at 617.
} 
Kirk (C1) had also borrowed money from the Bank of Scotland. Reid (C2) was a cautioner in respect of Kirk's liability to the bank, guaranteeing that Kirk would pay all sums for which he was, or might become, liable. ${ }^{98}$

Several features of these tripartite relationships should be noted. Firstly, C1 was the only obligant party to both relationship 1 and relationship 2. Secondly, C1 had two statuses: in relationship 1, he was a cautioner for D's debts; in relationship 2, he was a borrower whose liabilities were, in turn, guaranteed by another cautioner (C2). Thirdly, although $\mathrm{C} 1$ most likely had a contractual relationship with his principal debtor (D), and C2 most likely had a contractual relationship with his principal debtor $(\mathrm{C} 1)$, there does not appear to have been a contractual relationship between C2 and D. Fourthly, the creditor in each tripartite relationship was the same.

The dispute in this case arose from a payment made by $\mathrm{C} 2$ of a debt originally incurred by D. Following $\mathrm{C} 1$ 's death, the bank closed the various accounts in his and D's name and sought repayment of, inter alia, approximately $£ 2700$ stemming from D’s borrowings. ${ }^{99}$ Under relationship 1, $\mathrm{C} 1^{100}$ was liable as a cautioner for D’s $£ 2700$ debt. However, the sum was eventually paid to the bank not by $\mathrm{C} 1$ but by $\mathrm{C} 2$, who thereafter obtained an assignation of the debt from the bank and sought relief from D. ${ }^{101}$ This differs from the paradigm "relief" case: the sum incurred by $\mathrm{D}$ was not paid by his cautioner $(\mathrm{C} 1)$ but by his cautioner's cautioner $(\mathrm{C} 2)$; and now, rather than pursue his own principal debtor $(\mathrm{C} 1)$ for relief, the paying cautioner $(\mathrm{C} 2)$ claimed against his principal debtor's principal debtor (D). In contesting this claim, D argued that C2 had never been obliged to pay $£ 2700$ to the bank; hence, he could not recover this amount from D under a right of relief. ${ }^{102}$ This argument depended on a certain interpretation of C2's cautionary obligation in relationship 2: on a broad construction, C2 had guaranteed all of $\mathrm{C} 1$ 's debts to the bank, including $\mathrm{C} 1$ 's cautionary liability under relationship 1; on a narrow construction, C2's cautionary obligation was confined to debts arising from C1's borrowing from the bank, and did not extend to debts for which $\mathrm{C} 1$, himself, was a cautioner. This was no frivolous distinction. If the broad construction of C2's guarantee were correct, C2's payment to the bank had been made under a binding cautionary obligation; if the narrow construction of C2's guarantee were favoured, C2 had paid the bank as a mere volunteer who could never have

\footnotetext{
98 ibid 617.

$99 \mathrm{ibid}$. The precise figure was $£ 2704,13 \mathrm{~s}, 1 \mathrm{~d}$.

${ }^{100}$ Or rather his representatives, C1 having died.

${ }^{101}$ Reid v Lord Ruthven (1918) 55 SLR 616 at 617.

102 ibid 616-617.
} 
been sued for the payment, in which case $\mathrm{C} 2$ had no right of relief. In addition, D argued that, even if the broad construction of C2's cautionary obligation were favoured, and C2 had therefore been liable to pay $£ 2700$ to the bank, C1 was the only party from whom he could claim relief. ${ }^{103}$ Implicit in this argument was the assumption that a right of total relief depends on a contract between the cautioner and the principal debtor, hence that such a right lies only against the particular principal debtor at whose request one became bound.

The Lord Ordinary (Anderson)'s decision consisted not so much in confronting the defender's arguments as in deftly sidestepping them. He held that $\mathrm{C} 2$ enjoyed a right to repayment from D, but, apparently because D had cast doubt on C2's right of relief qua cautioner, he sought to place C2's right on a different footing. The Lord Ordinary argued that, even if C2 had paid the $£ 2700$ as a volunteer who was under no obligation to pay and who knew that he was under no such obligation, rather than as a cautioner, he would still have been entitled to reclaim that sum from D. ${ }^{104}$ This decision was upheld by the Inner House, which did little to elaborate on the reasoning in the court below. ${ }^{105}$ The Lord Ordinary gave two potential explanations for C2's right of recovery. Firstly, he could be deemed, in paying D's debt, to have acted as a negotiorum gestor for Ruthven (D). ${ }^{106}$ Secondly, and more importantly for present purposes, the Lord Ordinary went on to say that a volunteer paying another's debt is entitled to reclaim the amount paid from the debtor on the ground that the payment was made "with no intention of [donation]" on the debtor's "behalf". ${ }^{107}$ It is the latter explanation which has, in recent years, prompted an analysis of Reid v Lord Ruthven in terms of unjustified enrichment. D was enriched unjustifiably at the expense of $\mathrm{C} 2$, the latter having discharged a debt that was not his own. ${ }^{108}$ Accordingly, $\mathrm{C} 2$ was entitled to have this enrichment reversed.

\section{An Alternative Analysis of Reid v Lord Ruthven}

The Lord Ordinary's resort to an "enrichment" (and negotiorum gestio) analysis can be attributed to various factors. As noted already, Ruthven (D) had impugned the scope of Reid (C2)'s cautionary obligation, hence the necessity of his payment to the bank, which in turn cast doubt on the availability of a right of relief. There was also a potential problem with the bank's

\footnotetext{
103 ibid 617.

104 (1918) 55 SLR 616 at 618.

105 ibid 619.

106 ibid 618.

107 ibid.

${ }^{108}$ MacQueen, "Payment of another's debt" (n 86) at 470; Evans-Jones, Vol 2 (n 1) paras 6.52-6.54.
} 
assignation of the debt to $\mathrm{C} 2,{ }^{109}$ which may have served as a further incentive to root $\mathrm{C} 2$ 's right of recovery on a basis other than "relief". ${ }^{110}$ However, whether these factors compelled resort to an "enrichment" analysis is questionable. The Lord Ordinary expressly affirmed that C2's cautionary obligation had covered not only debts stemming from $\mathrm{C} 1$ 's borrowing but $\mathrm{C} 1$ 's debts qua cautioner; hence, he was convinced that $\mathrm{C} 2$ had paid the bank as a cautioner under a valid cautionary obligation rather than as a volunteer who was under no such obligation and who knew that he was under no such obligation. Further, even if there were potentially problems relating to the assignation, these did not rule out the existence of a right of relief. Of course, an assignation is desirable, chiefly because it allows the cautioner to benefit from the creditor's securities, but a cautioner's right to an assignation flows from his right of relief rather than vice versa. ${ }^{111}$ Why, then, did the Lord Ordinary analyse this case in terms of "enrichment" rather than "relief"? One potentially crucial factor in drawing the Lord Ordinary to an "enrichment" analysis of Reid v Lord Ruthven was the unusual nature of the facts before him, which differed from the paradigm "total relief" case involving one cautioner, one principal debtor and one creditor. Normally, a cautioner has a direct contractual relationship with the principal debtor based on the fact that the cautioner acts at the latter's behest, and the cautioner's right to total relief stems from that contract. ${ }^{12}$ The facts of Reid v Lord Ruthven resisted analysis in such terms, there having been no contractual relationship between D and $\mathrm{C} 2$ on which to base a right of relief. It was perhaps to circumnavigate that difficulty that the Lord Ordinary invoked unjustified enrichment (and negotiorum gestio) as the basis for his decision. Again, however, it is submitted that this was not a strong reason for avoiding a "relief" analysis. Once it is appreciated that a right of relief can be justified on a non-contractual basis, and once it is appreciated that $\mathrm{C} 2$ paid in his capacity as cautioner rather than as a volunteer who was under no obligation to pay, it becomes increasingly clear that $\mathrm{C} 2 \mathrm{did}$, in principle, enjoy a right of relief against $D$.

As discussed earlier, Kames' non-contractual explanation of relief is best understood from the creditor's perspective. ${ }^{113}$ In Reid $v$ Lord Ruthven, the bank had multiple persons from whom it could exact payment of the $£ 2700$. Lord Ruthven (D), as the borrower of the money, was the principal debtor, and Kirk (C1) was his cautioner. Reid (C2), in turn, was Kirk's

\footnotetext{
${ }^{109}$ As Lord Johnston remarked in the Inner House, a "verbal criticism" could be made regarding the assignation, but this criticism did not have "any substance": Reid v Lord Ruthven (1918) 55 SLR 616 at 619.

${ }^{110}$ Evans-Jones, vol 2 (n 1) paras 6.52-6.54.

${ }^{111}$ Kames, Principles (n 24) 79.

112 Baron D Hume, Lectures:1786-1822, vol II (G Campbell H Paton ed, Stair Society 1949) 214-215.

${ }^{113}$ Kames, Principles (n 24) 77-81.
} 
cautioner for, inter alia, the $£ 2700$. Thus, the creditor would have known that Reid (C2) was merely a secondary debtor in relation to Ruthven (D). ${ }^{114}$ Because there was no requirement to pursue and do diligence against $\mathrm{D}$ in the first instance, ${ }^{115}$ the bank had the right, following the default of D and C1, to exact full payment from C2. However, as Kames' equitable principle shows, there are limits on the creditor's power to act arbitrarily vis-à-vis obligants for the same debt. The bank could exact full payment from whomever it chose (D, C1 or C2) but that did not mean that the person who paid the bank (C2) had to bear the ultimate burden of liability. The paying cautioner is, in so far as this is not contrary to the creditor's interests, entitled to total relief from anyone who relative to him is a principal debtor. ${ }^{116}$ In sum, C2 was entitled to full relief from D, not because of some contractual relationship between them, but rather on account of the fact that they were common debtors to a common creditor; that $\mathrm{D}$, as a primary debtor relative to $\mathrm{C} 2$, ought to bear the ultimate burden of liability; and that the creditor, having received full payment of its debt, could in no way be prejudiced by C2's obtaining full relief from D. It is interesting to note that, almost three hundred years before Reid $v$ Lord Ruthven, a very similar case was decided in terms of a right of relief. ${ }^{117}$ While it is unlikely that the court in that case had in mind the abstract principle of relief that would later be propounded by Kames, ${ }^{118}$ the decision demonstrates that, as far back as 1636 , the notion of a right of relief was sufficiently broad to accommodate unusual cases, as where a cautioner and principal debtor have no contractual relationship inter se.

Why might it be appropriate to reappraise Reid v Lord Ruthven in terms of Kames' principle of "relief", in preference to the "enrichment" (and negotiorum gestio) analysis on which the Lord Ordinary actually relied? The reason for favouring a "relief" analysis is that it accurately reflects the basis on which Reid (C2) paid the creditor: namely, as someone who

\footnotetext{
${ }^{114}$ Generally speaking, multiple debtors are presumed to be liable on an equal footing unless there is evidence to suggest that one is liable on a secondary basis only: Smiton v Millar (1792) Mor 2138 at 2140; Crosbie v Brown (1900) $3 \mathrm{~F} 83$ at 86 . To cite a classic example, if a borrower's friends become liable for his bank loan, the friends are liable on a secondary basis because only the borrower benefits from the loan: Paterson $v$ Bonar (1844) 6 D 987. The presumption of equal liability may also be rebutted by a contract between the debtors to the effect that one is liable on a secondary basis only. Neither of these factors ("benefit" or "contract") were of assistance in Reid v Lord Ruthven: C2 had not become liable to the creditor for D's benefit; still less was there a contract between D and C2. Nevertheless, C2's liability to the creditor was undoubtedly secondary to that of D, something that can be inferred logically from the two contractual relationships that did exist among the obligants: $\mathrm{D}$ was a principal debtor vis-à-vis $\mathrm{C} 1$, and $\mathrm{C} 1$ was a principal debtor vis-à-vis $\mathrm{C} 2$; hence, $\mathrm{D}$ was also a principal debtor vis-à-vis $\mathrm{C} 2$.

${ }_{115}$ Mercantile Law Amendment Act (Scotland) 1856 s 8.

${ }^{116}$ Kames, Principles (n 24) 77-81.

${ }^{117}$ Lybrack v Vaus (1636) Mor 2118.

118 The court's emphasis was on the fact that C2 [i.e. the party comparable to Reid in Lybrack $v$ Vaus] was only sued by the creditor because he had become liable for a debt in which D was primarily liable: “... by [D's] occasion, [C2] had been distressed with payment ..." (ibid at 2118).
} 
was bound to do so under a valid cautionary obligation. Indeed, that C2 was obliged to pay the $£ 2700$ under a binding cautionary obligation was expressly affirmed by the Lord Ordinary. ${ }^{119}$ This is significant because it is payment of a common debt, owed by both the payer and the party from whom relief is sought, as opposed to the voluntary payment of another's debt, that triggers Kames' equitable principle. Conversely, unjustified enrichment was inappropriate because, where a payment is made pursuant to a contractual obligation, and the contract in question is valid, the payment cannot be recovered under the law of unjustified enrichment. ${ }^{120}$ This was a distinction of which even Lord Rodger, one of the most prominent judges to conflate unjustified enrichment and rights of relief, was all too cognisant:

The availability of this right of relief was disputed among Civil Law scholars for centuries - since in paying the creditor the cautioner had merely been performing his contractual obligation and any resulting enrichment of the co-obligant was therefore, so ran the argument, not unjust...121

Thus, even if it is accepted that the cautioner (C2) in Reid v Lord Ruthven enriched the principal debtor (D) by discharging his debt, itself a questionable proposition, ${ }^{122}$ it is hard to characterise that "enrichment" as "without legal ground" if C2 was obliged to make it under his contract with the bank. What might appear a dry taxonomical observation actually points to a fundamental distinction between rights of relief and unjustified enrichment. Unjustified enrichment concerns the irregular and the unpredictable: transactions that have gone awry; contracts that have failed to come into existence; future purposes that have failed; the spontaneous discharge of other parties' debts; and so on. ${ }^{123}$ A right of relief, at least as conceptualised by Kames, has a fundamentally different focus. Far from concerning a transaction that has gone wrong or an unexpected transfer of wealth, it presupposes that a number of events have run their predictable, contractually-determined course: the cautioner becomes bound to the creditor to pay if the principal debtor defaults; the principal debtor defaults; the cautioner, in accordance with his contractual undertaking, pays the creditor. Only following that sequence of events is the cautioner entitled to relief.

\footnotetext{
${ }^{119}$ Reid v Lord Ruthven (1918) 55 SLR 616 at 618.

${ }^{120}$ Dollar Land (Cumbernauld) Ltd v CIN Properties Ltd 1998 SC (HL) 90 at 94. That said, even the seemingly clear-cut distinction between contract and unjustified enrichment has not been immune to taxonomical boundary disputes: R Evans-Jones, "Unjust enrichment, contract and the third reception of Roman law in Scotland"

(1993) 109 LQR 663; MacQueen, "Future” (n 48) 24-27; Gloag and Henderson (n 1) para 24.23.

${ }^{121}$ Caledonia North Sea Ltd v London Bridge Engineering Ltd 2000 SLT 1123 at 1141 (emphasis added).

122 Bell, Prin $§ 558$. See also text to nn 124-130 below.

${ }^{123}$ Whitty, "Transco" (n 90) at 124.
} 
Admittedly, the significance of the "relief'/“enrichment" dichotomy may have been lost on the pursuer in Reid v Lord Ruthven. Reid's claim was successful and, given that Ruthven appears to have been solvent, he most likely viewed the label attached to his claim with a certain equanimity. However, in a different case, the designation of the pursuer's right as one of "enrichment" rather than "relief" may be critically important, most notably where the principal debtor is insolvent. A claim based on unjustified enrichment via P's voluntary payment of D's debt necessarily entails the discharge of a debt owed by $\mathrm{D},{ }^{124}$ thus rendering the claim incompatible with a subsequent assignation of the creditor's rights. ${ }^{125}$ The main practical consequence of this is that a right in unjustified enrichment based on the discharge of another's debt is, by definition, unsecured. ${ }^{126}$ There is no prospect, as in the case of a right of relief, of the payer's obtaining a security from the creditor to bolster his claim in unjustified enrichment, for the obligation to which that security relates no longer exists. ${ }^{127}$ Contrast this with the position of a cautioner, who, on paying the creditor, is seen to "buy" the latter's rights against the principal debtor rather than to discharge the principal debtor's debt, which is why the cautioner may, logically, give effect to his right of relief by demanding an assignation. ${ }^{128}$ Could this legal fiction be deployed to similar effect in the context of unjustified enrichment? One might argue that, where P voluntarily pays D's debt: (1) the payment unjustifiably enriches D by discharging his debt; but (2) this discharge is fictitious, meaning that the volunteer can enforce his right in unjustified enrichment via an assignation of the creditor's rights. ${ }^{129}$ The problem with this use of the "discharge" fiction is that it undermines P's cause of action. To say that the discharge of D's obligation is fictitious is to eliminate one of the essential components of an unjustified enrichment claim: enrichment of D at P's expense. ${ }^{130}$

\footnotetext{
${ }^{124}$ Wallace $v$ Braid (1900) 2 F 754.

${ }^{125}$ Tod v Dunlop (1838) 1 D 231. Nevertheless, in treating rights of relief as a form of unjustified enrichment, certain judges have begun to embrace this contradictory state of affairs, arguing that a cautioner both enriches the principal debtor by discharging the latter's debt and is entitled to an assignation of that selfsame debt: Caledonia North Sea Ltd v London Bridge Engineering Ltd 2000 SLT 1123 at 1143. This analysis has been criticised: R Williams, "Subrogation to rights of indemnity: Caledonia v London Bridge" (2001) 9 RLR 80 at 85 .

${ }^{126}$ Meier, "No Basis" (n 27) at 359, fn 84.

127 Wylie's Executrix v M'Jannet (1901) 4 F 195.

${ }^{128}$ Bell, Prin § 558. See similarly, Dannemann, German law (n 46) 17-18 and 117.

${ }^{129} \mathrm{C}$ Mitchell (n 8) at 205-207.

${ }^{130}$ Note e.g., the analysis of Lord Hodge in Gillespie Investments v Thomas Graham Gillespie [2011] CSOH 109, 2011 GWD 25-58 at para 20, where he states that payment by a party secondarily liable, in this case an indemnifier (A), does not discharge the claim of the creditor (B) against the party primarily liable for B's loss (C), but A is subrogated to B's rights against C in order to "reverse the unjustified enrichment of C by A's indemnity". It is difficult to see how $\mathrm{C}$ has been enriched by A's payment if the creditor's claim against him has not been discharged thereby.
} 
This section has not been intended as an outright critique of Reid v Lord Ruthven. The case gives expression to an important principle of unjustified enrichment via the voluntary payment of another's debt. The difficulty with the Lord Ordinary's decision is that he favoured an "enrichment" analysis where a "relief" analysis would have been more appropriate. That is not to deny that there were practical reasons for the course that the Lord Ordinary adopted. He was trying to show that if Reid could recover the money qua volunteer, he could recover it qua cautioner on an a fortiori basis. However, this pragmatism had unwelcome side-effects, obscuring what was arguably the true cause of action at work in the case (fulfilment of a common obligation), and suggesting that the difference between a right of relief and a right in unjustified enrichment is inconsequential.

\section{E. The Complementary Functions of "Relief" and "Enrichment"}

So far it has been argued that a clear conceptual distinction should be drawn between rights of relief and unjustified enrichment for the simple reason that they are mutually exclusive. Rights of relief arise from the fulfilment of a common obligation; rights in unjustified enrichment from, inter alia, the voluntary fulfilment of another's obligation. However, that is not to say that these two areas of law should be considered in mutual isolation: their functions, though distinct, are often complementary. Further, in certain borderline cases, it may be worthwhile relying on both "relief" and "unjustified enrichment" as alternative grounds for recovery.

Because rights of relief depend on the fulfilment of a common obligation, a cautioner cannot claim relief from his principal debtor if the latter's obligation was not due. ${ }^{131}$ However, the cautioner may still be able to recover his payment from the creditor if he erroneously believed that the debt was due (condictio indebiti), ${ }^{132}$ or if the cautioner's payment, though due at the time, was subsequently rendered "without legal ground" when the principal debtor paid the same sum to the creditor. ${ }^{133}$ In like manner, where a cautioner pays a sum that was owed by the principal debtor but for which the cautioner himself was not liable, a right of relief is untenable, because such a claim depends on the cautioner's having paid a debt that was owed by both him and the principal debtor. ${ }^{134}$ Nevertheless, in such cases, the cautioner may still

\footnotetext{
${ }^{131}$ Maxwel v Nithsdale (1632) Mor 2115; Cheltenham \& Gloucester Plc v Sun Alliance and London Insurance Plc 2001 SC 965 at 971-973 per Lord President Rodger.

${ }^{132}$ Carrick v Carse (1778) Mor 2931.

133 Patten $v$ Royal Bank (1853) 15 D 617. This is an instance of the condictio ob causam finitam: the claim to recover a benefit given for a purpose that succeeded initially but failed later on. For more details, see D.12.7.2; Zimmermann, Obligations (n 43) 855-56; Evans-Jones, Vol 1 (n 1) paras 6.06-6.11; M Hogg, "Unjustified enrichment claims: when does the prescriptive clock begin to run?" Edin LR 405 at 406-407.

${ }^{134}$ Henderson v Paul (1867) 5 M 628 at 630-631; Morgan v Smart (1872) 10 M 610; Bell, Prin, 10th edn, $\S 62$.
} 
enjoy a right in unjustified enrichment. Again, if he paid the money in the erroneous belief that it was due under his cautionary obligation, he may be able to recover it from the creditor under the condictio indebiti. ${ }^{135}$ Alternatively, even if the cautioner was aware that he did not owe the money qua cautioner, he may be able to claim against the principal debtor in unjustified enrichment on the ground that he voluntarily discharged the latter's debt. ${ }^{136}$ That, of course, was the basis of the Lord Ordinary's decision in Reid v Lord Ruthven. ${ }^{137}$

The practical merits of advancing pleas based on a right of relief, unjustified enrichment or both in the alternative will depend on the facts of the case under consideration. It may be more difficult to substantiate a right of relief than a claim based on unjustified enrichment, or vice versa. Again, this stems from the fact that a right of relief and a right arising from unjustified enrichment are based on distinct causative events. A claim based on unjustified enrichment will raise different issues from those raised by a right of relief, for example the circumstances in which a volunteer may discharge a third party's debt where either the creditor or debtor objects, ${ }^{138}$ for if the debtor's debt has not been discharged, he has not been enriched. Of course, usually, "a creditor is only too anxious to receive payment", ${ }^{139}$ and a debtor will often be indifferent as to the identity of his creditor. Further, in line with the civilian tradition, ${ }^{140}$ Scots law recognises the power of a third party to discharge another's monetary debt without

\footnotetext{
${ }^{135}$ Morgan Guaranty Trust Company of New York v Lothian Regional Council 1995 SC 151.

${ }^{136}$ Inglis $v$ Gunn and Robertson (1828) 6 S 405 . Here two cautioners who had guaranteed the completion of a building project paid a $£ 40$ debt owed by their insolvent principal debtor but for which they were not liable as cautioners. They were found entitled to recover $£ 40$ from the principal debtor's estate and to rank preferentially therefor in terms of an agreement between them and the debtor's other creditors. Although this case was not decided in terms of unjustified enrichment, that would have afforded a solid non-contractual basis for the cautioners' right of recovery. The cautioners discharged the $£ 40$ debt voluntarily, thereby enriching the debtor's estate, and they did so for legitimate reasons: payment of the $£ 40$ allowed the cautioners to obtain a large quantity of wood held in security of that debt, which was then used by the debtor's other creditors to complete the building project, and thus to obtain payment of the price for that project into his insolvent estate. However, had the cautioners' claim been based on unjustified enrichment, they would not have been entitled to rank preferentially for the £40: Wylie’s Executrix v M'Jannet (1901) 4 F 195.

137 (1918) 55 SLR 616.

${ }^{138}$ Macgregor and Whitty (n 75) at 63-70. As regards the creditor's right to refuse a tendered payment, there are at least two types of case: (1) cases in which a volunteer tenders payment to a creditor in an attempt to discharge a third party's debt, intending thereafter to seek reimbursement from the debtor; (2) cases in which a volunteer tenders payment to a creditor but also demands an assignation of the creditor's rights against the debtor. Only category (1) concerns unjustified enrichment sensu stricto, but some cases in category (2) demonstrate when a volunteer is entitled to pay a creditor against the latter's will, e.g. Smith v Gentle (1844) 6 D 1164.

${ }^{139}$ Whitbread Group Plc v Goldapple Ltd (No 2) 2005 SLT 281 at para 11 per Lord Drummond Young.

${ }^{140}$ Justinian III, 29, pr. This continues to find support in such modern civilian systems as Germany (BGB § 267) and in such codification models as DCFR III, 2.107. Cf the position in English law: S Meier, "Performance of an obligation by a third party" in A Burrows, D Johnston and R Zimmermann, Judge and Jurist: Essays in Memory of Lord Rodger of Earlsferry (2013) 619 at 625-630.
} 
the latter's authorisation, ${ }^{141}$ nay, even if the latter expressly objects. ${ }^{142}$ Nevertheless, there are exceptions to this general rule. There may be cases in which the creditor has a special interest in exacting payment from the debtor himself. ${ }^{143}$ If, say, a landlord is offered payment of rent arrears by someone other than the tenant, the landlord may refuse the tendered payment if he feels that, by accepting it, he is tacitly recognising the third party as a new tenant. ${ }^{144}$ The unauthorised discharge of another's debt may also be incompetent if the creditor has not yet demanded payment from the debtor or taken steps to enforce the debt, ${ }^{145}$ or where both the debtor and creditor object to the payment. ${ }^{146}$ Moreover, even if a volunteer's payment is accepted by the creditor, the law will not always treat this payment as a discharge of the debtor's obligation. ${ }^{147}$

On account of such considerations, it may be preferable in a borderline case to claim that one paid as a cautioner or co-obligant rather than as someone who was under no obligation to pay. Because a cautioner is, himself, an obligant, neither the principal debtor nor the creditor can object to his paying the debt. The mere fact of being a cautioner, and the attendant risk of being sued if the principal debtor defaults, affords the former a "right to intervene", ${ }^{148}$ and to remove thereby the "cloud of debt hanging over him". ${ }^{149}$ This means that, as soon as the

\footnotetext{
${ }^{141}$ Bankton, Inst I.24.2; Bell, Prin § 557; Smith v Gentle (1844) 6 D 1164; Reid v Lord Ruthven (1918) 55 SLR 616; Gloag and Henderson (n 1) para 3.23. Other cases involving voluntary payments are at least consistent with the view that a third party may discharge another's debt without the latter's authorisation: see, e.g., Duncan v Motherwell Bridge \& Engineering Co Ltd 1952 SC 131. Cf Kames, Principles (n 24) 286-287 and Baron D Hume, Lectures, 1786-1822, vol III, G Campbell H Paton ed (1952) 16-17, where it is suggested that the debtor must ratify the payment before it effects a discharge of his debt. These alternative views have proved uninfluential: Macgregor and Whitty (n 75) at 64. Similarly, although Lord President Rodger equivocated on the matter in Caledonia North Sea Ltd v London Bridge Engineering Ltd 2000 SLT 1123 at 1144-1145, the only Scottish source he cited in this regard supported a right of unauthorised discharge: Whitty, "Negotiorum gestio" (n 76) para 97.

${ }^{142}$ Bankton, Inst I.24.2; Bell, Prin, 4th and 10th edn, § 557.

${ }^{143}$ See Bell, Prin $\S 557$, which, as interpreted in Macgregor and Whitty (n 75) 62-69, gives expression to four requirements for the voluntary discharge of another's monetary debt: (1) the debt must be "due" and "demanded"; (2) delay in payment must carry a potential "penal effect" such as the execution of diligence; (3) the creditor must have no interest in demanding payment from the true debtor; and (4) either the debtor or creditor must not object to the third party's payment. See also, J Erskine, Principles of the Law of Scotland, 21st edn, by J Rankine (1911) 509.

${ }^{144}$ Whitbread Group Plc v Goldapple Ltd (No 2) 2005 SLT 281 at paras 14-15.

145 Bell, Prin, 4th and 10th edn, § 557; Smith v Gentle (1844) 6 D 1164; Fleming v Burgess (1867) 5 M 856 at 861 per Lord Neaves; WW McBryde, The Law of Contract in Scotland, 3rd edn (2007) para 12.102.

${ }^{146}$ Gloag and Henderson (n 1) at para 3.23. Even in such cases, the volunteer may still have a right to discharge the debt if he can show that he (the volunteer) will be prejudiced by the creditor's enforcement of the debt, as where the volunteer has a proprietary or possessory interest in property owned by the debtor: D Friedmann and N Cohen, "Payment of another's debt" in P Schlechtriem (ed), Restitution - Unjust Enrichment and Negotiorum Gestio, vol X, ch 10 of The International Encyclopaedia of Comparative Law (1991) para 3.

${ }^{147}$ Norwich Union Fire Insurance Society Ltd v Ross 1995 SLT (Sh Ct) 103, in which the sheriff applied Esso Petroleum Co Ltd v Hall Russell \& Co Ltd 1988 SLT 874 at 878 per Lord Goff.

${ }^{148}$ Marshall $v$ Pennycook 1908 SC 276 at 285 per Lord Low.

${ }^{149}$ Moss v Penman 1993 SC 300 at 302 per Lord President Hope.
} 
principal debtor's obligation falls due, and regardless of whether the creditor has demanded payment from the cautioner or taken steps to enforce it against the principal debtor, the cautioner is entitled to pay the creditor and seek relief from the principal debtor or cocautioners. ${ }^{150}$ Whereas a voluntary payer sometimes has to demonstrate a legitimate interest in paying the creditor, a cautioner's legitimate interest is presumed. ${ }^{151}$ Furthermore, a cautioner's right of relief does not depend on his having discharged the principal debtor's obligation; he simply needs to have suffered loss as a result of discharging his own cautionary obligation. ${ }^{152}$ On the contrary, if the payer desires an assignation of securities from the creditor, he should avoid invoking unjustified enrichment: a ground of action that depends, by definition, on the very rights to which he seeks an assignation having been discharged. ${ }^{153}$

In some cases, the characterisation of a claim as one of "enrichment" or "relief" will be of little moment. There is, for instance, nothing practically to distinguish the content of a cautioner's claim of total relief for paying a debt of 100 and the content of a claim in unjustified enrichment for the voluntary payment of a debt of 100: the measure of recovery will be 100 in either case. Furthermore, both rights of relief and rights in unjustified enrichment for the voluntary payment of another's debt are, albeit for different reasons, subject to defences that the debtor could have invoked against the creditor. ${ }^{154}$ Again, however, some obstacles to recovery are peculiar to the law of unjustified enrichment, and this is crucially connected to the fact that a claim in unjustified enrichment depends, as the name suggests, on the defender's having been enriched. This point is neatly illustrated by Brown v Meek's Trustees. ${ }^{155}$ Here a trustee, who had with his own funds paid the premiums on a life insurance policy forming part of the trust estate, demanded that the policy, which had not yet matured, be realised so that he could obtain reimbursement of the premiums therefrom. His claim was dismissed as premature. At the time of the claim, the surrender value of the policy was less than the premiums paid by the trustee, and so it would have been completely exhausted by the trustee's "enrichment" claim. In fact, had the trustee not intervened at all by paying the premiums, and simply allowed

\footnotetext{
${ }^{150}$ Gray v Thomson (1847) 10 D 145; Moss v Penman 1993 SC 300.

${ }^{151}$ Bell, Prin $\S 558 ;$ Smith v Gentle (1844) 6 D 1164. See also Lord Shand's dissenting judgment in Guthrie and M'Connachy v Smith (1880) 8 R 107 at 113-117.

152 Bell, Prin § 558; Marshall v Pennycook 1908 SC 276.

${ }^{153}$ Tod v Dunlop (1838) 1 D 231.

${ }^{154}$ When a cautioner steps into the creditor's shoes, his rights against the principal debtor are "no more and no less" than those previously enjoyed by the creditor: Esso Petroleum Co Ltd v Hall Russell \& Co Ltd 1988 SLT 874 at 882 per Lord Jauncey. To similar effect, if a volunteer fulfils another's obligation and the debtor could have invoked a defence against the creditor, the volunteer's "enrichment" claim may, in principle, be met with that selfsame defence on the ground that his payment has not actually enriched the debtor: MacGregor and Whitty (n 75) 70. 155 (1896) 4 SLT 46.
} 
the policy to lapse, the trust estate would have been better off overall. ${ }^{156} \mathrm{~A}$ right of relief, which does not depend on the defender's having been enriched, would not have been defeated in this way.

\section{F. Conclusion}

If rights of relief and unjustified enrichment are distinct sources of law, it is important to underline in what respects they are distinct. Broadly stated, rights of relief concern the redistribution of loss suffered by multiple obligants in the same obligation, the operative relationship being that of common liability to a common creditor. Unjustified enrichment, by contrast, seeks to set right transfers arising from misunderstandings, disappointed expectations and various other unusual circumstances. The key relationship consists not in co-obligants' liability to a common creditor but in enrichment of the defender at the pursuer's expense. Once those profound functional differences are understood, it becomes far easier to discern which legal area, if either, applies in a difficult case. It also becomes clearer how these two areas interact. As a general rule, the existence of a right of relief rules out the possibility of a claim in unjustified enrichment: if, say, a cautioner's right of relief depends on the fulfilment of a valid cautionary obligation, it is difficult to view the cautioner's payment to the creditor as lacking a legal ground. At the same time, unjustified enrichment becomes important in circumstances where rights of relief are not available, as where a cautioner pays a debt that he did not owe and now seeks recourse from the debtor. It is in such cases that unjustified enrichment reveals its true worth as a supplement to rights of relief: a utility obscured by the judicial tendency to conflate these legal areas.

${ }^{156}$ See similarly, Morgan v Morgan's Judicial Factor 1922 SLT 247 at 251 per Lord Hunter. 